\title{
Miller revealed new ways to study the origins of life
}

\section{Science advances as one theory builds on another: Miller didn't just update Löb's work.}

Sir - Hubert P. Yockey in Correspondence (Nature 415, 833; 2002) claims that Stanley L. Miller's classical synthesis of amino acids and other organic compounds with electric discharges using possible prebiotic conditions (Science 117, 528; 1953) was a mere repetition of several previous electrochemical syntheses performed by Walther Löb and others in the early twentieth century. This is not a fair assessment of the significance of Miller's experiment.

Although some of Löb's results may have some bearing on our understanding of prebiotic syntheses, part of the significance of Miller's experiment lies not only in the production of amino acids and other compounds, but in their synthesis under what was viewed at the time as plausible primitive Earth conditions. Few, if any, scientific ideas are the product of spontaneous thoughts - most theories, experiments and interpretations have been preceded by many others, and the same is true of Miller's experiment. Even if one disagrees with the assumptions underlying the simulation by Miller and Harold Urey of the primitive Earth, it deserves recognition not only because of its intrinsic merits, but also because it opened new avenues of empirical research into the origin of life.

Löb did indeed report the synthesis of glycine by exposing wet formamide to a silent discharge (Ber. Dtsch Chem. Ges. 46, $684 ; 1913)$. He suggested that because of either the ultraviolet light or the electrical field generated by the silent discharge, formamide is first converted to oxamic acid, which in turn is reduced to glycine. He also claimed that glycine is produced when wet carbon monoxide and ammonia are subjected to the silent discharge; he proposed formamide as the intermediate in this synthesis. Löb theorized that glycine might also be produced from wet carbon dioxide and ammonia in a pathway wherein formamide was again the intermediate, but he did not demonstrate this directly.

Although Löb apparently did produce glycine from formamide, this cannot be considered a prebiotic reaction because formamide would not have been present on the primitive Earth in any significant concentrations. It is also possible that the wet carbon monoxide and ammonia led to HCN synthesis, which would have produced glycine on polymerization and hydrolysis.

From a careful reading of Löb's 1913 paper (in early twentieth-century German!) it is clear that his motivation for doing the experiment was to try to understand the assimilation of carbon dioxide and nitrogen in plants. There is no indication that he had any interest in the question of how life began on Earth, or in the synthesis of organic compounds under possible prebiotic conditions. Neither Aleksander Oparin, J. B. S. Haldane nor Urey made any mention of Löb's work, which given Oparin's extensive review of early relevant literature suggests it was considered unimportant. To the best of our knowledge, Löb's work was first discussed within the context of prebiotic chemistry by Miller (J. Am. Chem. Soc. 77, 2351; 1955).

Jeffrey L. Bada ${ }^{\star}$ and Antonio Lazcano $\dagger$

${ }^{*}$ Scripps Institution of Oceanography,

University of California at San Diego, La Jolla, California 92093-0212, USA

$\dagger$ Facultad de Ciencias, UNAM/Apdo. Postal 70407, Ciudad Universitaria, 04510 Mexico D. F., Mexico

\section{Communication should not be left to scientists}

Sir - The time has come for the professionalization of science communicators. Not only are the number of degree programmes in science communication growing, but rudiments of a professional code of conduct have now been published. Although there is nothing new about the advice given in Guidelines on Science and Health Communication, issued in November 2001 by the Social Issues Research Centre in partnership with the Royal Society and the Royal Institution (see www.sirc.org/publik/revised_ guidelines.shtml), what is striking is that it is directed at science communicators by people who are not themselves full-time science communicators.

This pattern is familiar from the history of such 'mediating' professions as nursing and librarianship. Members of a senior profession typically try to formulate the aims of the newer profession in terms of their own interests. Physicians have tried to set nursing codes, academics librarian codes, and now scientists are trying to set codes for science communication.

At the same time, however, the mediating professions have often provided their own visions, which in significant respects cut against those of the senior professions. For example, Florence Nightingale did not want nurses to make it easier for doctors to administer medicine, but to provide a total healing environment that would eventually prevent the need for doctors. Similarly, Melvil Dewey's cataloguing system envisaged librarians, not as dutiful retrievers of books, but as the last encyclopaedists in a world where knowledge was quickly fragmenting.

To be sure, nursing and librarianship have not been completely successful in their professionalization. Nevertheless, their histories provide valuable lessons for science communicators. The public profile of nurses and librarians was raised as physicians and academics, respectively, became increasingly specialized. This led ambitious members of the mediating profession to occupy the role previously filled by the 'general practitioner' of the senior profession: someone sufficiently familiar both with a broad range of specialist knowledge and with clients' particular needs to make the knowledge meaningful for them.

If the history of the mediating professions is a guide, the idea of science communicators as general practitioners of science may well generate conflict with professional scientists. Whenever someone claims that Richard Dawkins's The Selfish Gene has done more for biology than most front-line research in the field, we get a taste of those potential battles.

Nevertheless, by involving the general public, science communication is uniquely placed to make good the idea that science is truly universal knowledge. The current guidelines reduce communication to the one-way transmission of accurate information. More ambitious professional guidelines would require a feedback element in any form of science communication, whether it be as letters to the editor, Internet chat rooms or the interactive exhibits now routine in good museums.

The current guidelines pitch the aims of science communication too low. The field should aspire not simply to make people trust science but to make them feel part of it. This is more than encouraging people to become scientists. Science communication will truly come of age when people regard participating in a scientific experiment as a civic duty on par with jury duty. We are far from that day, but it is not too early for full-time science communicators to convene formally to draft some professional codes of conduct.

Steve Fuller

Department of Sociology, University of Warwick, Coventry CV4 7AL, UK 